\title{
Detection of Borrelia burgdorferi sensu lato and spotted fever group rickettsiae in hard ticks (Acari, Ixodidae) parasitizing bats in Poland
}

\author{
Krzysztof Piksa $^{1}$ - Joanna Stańczak ${ }^{2}$ - Beata Biernat ${ }^{2}$ • Andrzej Górz ${ }^{3}$. \\ Magdalena Nowak-Chmura ${ }^{3} \cdot$ Krzysztof Siuda $^{3}$
}

Received: 2 June 2015 / Accepted: 20 January 2016 / Published online: 2 February 2016

(C) The Author(s) 2016. This article is published with open access at Springerlink.com

\begin{abstract}
A total of 491 Ixodes vespertilionis and 8 Ixodes ricinus collected from bats and cave walls in southern Poland between 2010 and 2012 were examined by the polymerase chain reaction for tick-transmitted pathogens. PCR analysis for Borrelia burgdorferi s.1., Rickettsia spp., and Anaplasma phagocytophilum yielded negative results for all I. vespertilionis. DNA of Rickettsia helvetica was detected in three specimens of I. ricinus attached to Rhinolophus hipposideros or Myotis myotis, while Borrelia garinii was found in one tick parasitizing Myotis daubentonii. These pathogens were recorded for the first time in hard ticks that parasitized bats.
\end{abstract}

Keywords Bats, ticks $\cdot$ Ectoparasites $\cdot$ Borrelia burgdorferi s.l. $\cdot$ SFG Rickettsia $\cdot$ Poland

\section{Introduction}

Multiple sources report that ticks are reservoirs and vectors of a variety of pathogens (Jongejan and Uilenberg

Krzysztof Piksa

krzychu@up.krakow.pl

1 Department of Vertebrate Zoology and Human Biology, Institute of Biology, Cracow Pedagogical University, Podbrzezie 3, 31-054 Kraków, Poland

2 Department of Tropical Parasitology, Medical University of Gdańsk, 9B Powstania Styczniowego str., 81-519 Gdynia, Poland

3 Department of Invertebrate Zoology and Parasitology, Institute of Biology, Cracow Pedagogical University, Podbrzezie 3, 31-054 Kraków, Poland
2004). Of 78 tick species recorded in Europe (NowakChmura and Siuda 2012; Hornok et al. 2014) five hard ticks (Ixodes vespertilionis, I. simplex, I. ariadnae, I. ricinus and I. trianguliceps) and one soft tick (Carios vespertilionis) were recorded on bats (Haitlinger 1978; Hornok et al. 2014; Siuda et al. 2009; Ševčík et al. 2010). Of these, only I. vespertilionis, I. simplex, and I. ariadnae are specific parasites of bats. They mainly inhabit caves and cave-like shelters (Filippova 1977; Hornok et al. 2014; Siuda et al. 2009; Ševčík et al. 2010). In contrast, Ixodes ricinus and I. trianguliceps are exophilic species that parasitize a wide range of vertebrate hosts (Eisen and Lane 2002; Hillyard 1996) which occasionally includes bats (Piksa et al. 2014; Siuda et al. 2009; Ševčík et al. 2010). Both species are the important vectors of pathogenic agents in Europe (Bown et al. 2008; Gray 1998; Süss et al. 2008).

Chiroptera are the second most specious mammalian order next to rodents; currently, over 1300 species are known (Fenton and Simmons 2015). However, despite the high species richness of bats, there are almost no reports on vectorborne agents occurring in ticks parasitizing these mammals. So far, Borrelia spp., including Borrelia burgdorferi sensu lato, Rickettsia spp., and Ehrlichia spp. have been found in the soft tick C. vespertilionis (also known as Argas vespertilionis) (Hubbard et al. 1998; Socolovschi et al. 2012), while Rickettsia spp., Borrelia spp., and Bartonella spp. were detected in Carios kelleyi (Loftis et al. 2005). On the other hand, of hard tick species associated with bats, only in I. vespertilionis such pathogenic agents as Bartonella spp. were found (Hornok et al. 2012).

Results of recent studies indicate that immature and adult stages of ticks are being frequently found on bats in Poland (Piksa et al. 2013; Siuda et al. 2009). These ticks potentially may serve as vectors of different pathogenic agents. Thus, the 
purpose of our preliminary study was to analyze ixodid ticks collected from different bat hosts for the presence of pathogenic Borrelia spp., Rickettsia spp., and Anaplasma phagocytophilum.

\section{Materials and methods}

\section{Tick collection}

Ticks were collected from (1) bats captured outside the caves into mist-nets and harp-traps during post-hibernal, summer, and swarming activity; (2) during hibernation period through direct collection from bats and from bats captured before the cave entrance; (3) handled from cave walls; and (4) during survey of bats in shelters of nursery colonies. Samples were collected between 2010 and 2012 in a dozen localities in the Polish Carpathians and Krakowska-Wieluńska Upland (Table 1). The fieldwork was carried out under permits issued by the Polish Ministry of Environment and the General Directorate for Environmental Protection (DLOPpn-4102517/24815/10/RS, DOPpn-4102-705/35666/11/RS, DLOPpozgis-4200/VI.D-3/1263/10/km, DOP-OZGIZ.6401. 09.18.2011.km.2).

All ticks were stored in $70 \%$ ethanol for morphological examination and subsequent molecular studies. Ticks were identified to species and developmental stage (larvae, nymphs, males, and females). The taxonomic identification of ticks was done using a light microscope by comparison with characteristics presented in taxonomic keys and with description of species found in papers by Siuda (1993), Arthur (1956) and Manilla (1998).

\section{DNA extraction and PCR analysis}

The total DNA was extracted from individual unfed ticks by lysis in ammonium hydroxide $\left(\mathrm{NH}_{4} \mathrm{OH}\right)$ (Rijpkema et al. 1996) and from ticks of different stages of engorgement by using Sherlock AX commercial kit (A\&A Biotechnology, Gdynia, Poland). The obtained lysates were kept at $-20{ }^{\circ} \mathrm{C}$. Regular, semi-nested and nested PCRs were performed in order to detect spirochetes of Borrelia spp., rickettsiae A. phagocytophilum, and Rickettsia spp.

A nested PCR was conducted to detect for the presence of Borrelia spp. within individual ticks. The protocol of Wodecka et al. (2009) was used to amplify 774- and 605-bp fragments of the fla gene, using primer pairs $132 \mathrm{f}$ and $905 \mathrm{r}$, and $220 \mathrm{f}$ and $824 \mathrm{r}$, respectively.

Another nested PCR assay was performed for the detection of A. phagocytophilum DNA. Primer pairs ge3a and ge10r, and ge9f and ge2, and the protocol of Massung et al. (2002), were used to amplify a 546-bp fragment of the bacterial $16 \mathrm{~S}$ rRNA gene.

Rickettsial DNA was detected by a regular PCR using primers RpCs.877p and RpCs.1258n, which amplify a 381bp fragment of the citrate synthase gene ( $g l t A)$ of Rickettsia spp. (Regnery et al. 1991). Then, positive samples were subjected to nested and semi-nested PCRs, designed to amplify a 355-bp region of the OmpA gene and 757-bp region of the $16 \mathrm{~S}$ rRNA gene, respectively. Nested PCR primes SLO1F/SLO1R (outer) and SLO2F/SLO2R (inner) as well as semi-nested primers Ric, Ric U8, and Ric Rt were used as previously described by Raoult et al. (2002) and Nilsson et al. (1997), respectively.

Each PCR reaction was performed in a reaction volume of $20 \mu \mathrm{L}$ containing $0.5 \mu \mathrm{L}$ RUN Taq polymerase $(1 \mathrm{U} / 1 \mu \mathrm{L})$
Table 1 The number of ticks examined for the presence of tick-borne pathogens

\begin{tabular}{|c|c|c|c|c|c|c|}
\hline \multirow[t]{2}{*}{ Tick species } & \multirow[t]{2}{*}{ Host species } & \multicolumn{5}{|c|}{ Number of collected specimens: } \\
\hline & & Larvae & Nymphs & Females & Males & Total \\
\hline \multirow[t]{7}{*}{ Ixodes vespertilionis } & Cave wall & & 42 & 75 & 46 & 163 \\
\hline & Rhinolophus hipposideros & 126 & 137 & 46 & & 309 \\
\hline & Myotis myotis & 1 & 1 & 1 & & 3 \\
\hline & Myotis nattereri & 6 & & & & 6 \\
\hline & Myotis emarginatus & 6 & 2 & & & 8 \\
\hline & Myotis brandtii & & & 1 & & 1 \\
\hline & Myotis mystacinus & & 1 & & & 1 \\
\hline Total & & 139 & 183 & 123 & 46 & 491 \\
\hline \multirow[t]{4}{*}{ Ixodes ricinus } & Rhinolophus hipposideros & & & 4 & & 4 \\
\hline & Myotis myotis & & & 1 & & 1 \\
\hline & Myotis bechsteinii & 1 & & & & 1 \\
\hline & Myotis daubentonii & & & 2 & & 2 \\
\hline Total & & 1 & 0 & 7 & 0 & 8 \\
\hline
\end{tabular}


(A\&A Biotechnology, Gdynia, Poland), $2 \mu \mathrm{L} 10 \times$ PCR Buffer (A\&A Biotechnology, Gdynia, Poland), $2 \mu \mathrm{L}$ dNTPs mixture (10 mM) (Fermentas, Lithuania), $0.4 \mu \mathrm{L}$ of appropriate primers, $12.7 \mu \mathrm{L}$ double distilled water $(13.7 \mu \mathrm{L}$ for seminested and nested PCR), and $2 \mu \mathrm{L}$ of the processed tick sample or $1 \mu \mathrm{L}$ of the obtained PCR product for the semi-nested and/or nested PCR. As positive controls served B. afzelii-, A. phagocytophilum-, and $R$. raoultii-positive tick samples from our previous investigations served as positive controls (Stańczak et al. 2004; Stańczak 2006). The negative control was sterile water (aqua pro injectione).

All reactions were carried out in the GeneAmp ${ }^{\circledR}$ thermocycler PCR System 9700 (Applied Biosystem 850, CA, USA). Amplification products were analyzed after electrophoresis in a $2 \%$ agarose gel stained with Midori Green DNA Stain (Nippon Genetics Europe GmbH).

PCR-positive products were purified with the clean-up purification kit (A\&A Biotechnology, Poland) and sequenced in both directions with an ABI 310 Genetic Analyzer (Applied Biosystems, Foster City, CA, USA) by using the BigDye Terminator Cycle Sequencing kit version 3.1. (Applied Biosystems, Carlsbad, CA, USA) and the same primer pairs as for regular [RpCS.877p and RpCs.1258n], semi-nested [Ric and Ric Rt], and nested [220f and 824r] amplification. All sequences were compared with the corresponding sequences deposited in GenBank using BLAST (www.ncbi. nlm.nih.gov.blast)

\section{Results}

A total of 499 ticks, including $491 \mathrm{I}$. vespertilionis (longlegged bat ticks) and 8 I. ricinus (sheep ticks) were selected from a few thousand ixodid ticks collected from bats in Poland in 2010-2012 (Table 1). All ticks were examined individually by PCR for the presence of Borrelia spp., A. phagocytophilum, and Rickettsia spp.

None of the examined long-legged bat ticks was found to be infected with any of the searched pathogens. None of the I. ricinus specimens was found to harbor A. phagocytophilum.

In contrast, Borrelia DNA was detected in one I. ricinus female (Table 2) parasitizing Myotis daubentonii. Subsequent sequencing of the 562-bp amplicon of the fla gene (GenBank acc. no. KJ577820) revealed that it was most similar (99.8 \%) to fla gene sequences of Borrelia garinii (GenBank acc.nos. KF836512, KF918608, JF828688).

Two I. ricinus females (Table 2) from Rhinolophus hipposideros and one I. ricinus female from M. myotis were PCR-positive for the rickettsial glt $A$ gene. The sequences were $100 \%$ homologous to each other and to the gltA sequences of Rickettsia helvetica (GeneBank acc nos. JX627379, KF447530, KC007126, JX040636, and AM418450). The consensus sequence ( $370 \mathrm{bp}$ ) was deposited in GenBank under acc. no. KJ577821. Moreover, the three positive samples were re-run and specific fragments of 16S rRNA gene of Rickettsia spp. were successfully amplified and sequenced. Also these sequences were identical and they shared $100 \%$ similarity to four of $R$. helvetica sequences available in GenBank: GQ413963; AF394904, AF394905; L36212. The consensus sequence (719 bp) was deposited in GenBank under acc. no. KJ577822. However, all three samples that were PCR-positive for the rickettsial glt $A$ gene were negative for the omp $A$ gene.

\section{Discussion}

The results of this preliminary study showed that some ixodid ticks collected from bats in southern Poland were infected with two species of pathogenic bacteria: $B$. garinii of $B$. burgdorferi sensu lato complex and $R$. helvetica of the spotted fever group rickettsiae (SFG). Both agents were detected in I. ricinus which is an accidental ectoparasite of bats in contrast to $I$. vespertilionis being a specific parasite of these hosts.

The role of a long-legged bat tick I. vespertilionis as a vector and reservoir of bacterial, viral, or protozoan pathogens is almost unknown. Until now, from bacterial agents, only Bartonella spp. has been detected in free-living individuals collected from cave walls (Hornok et al. 2012). The absence of Borrelia spp., Rickettsia spp., and A. phagocytophilum in I. vespertilionis tested in the present study indicate that this tick species is of little epidemiological significance.

In contrast, $R$. helvetica of SFG and $B$. garinii spirochetes were detected in three and one, respectively, different females of I. ricinus detached from bats. The presence of these bacteria in
Table 2 Tick-borne bacteria detected in Ixodes ricnus collected from bats

\begin{tabular}{|c|c|c|c|c|}
\hline \multirow[t]{2}{*}{ Tick species and stage } & \multirow[t]{2}{*}{ No. ticks tested } & \multicolumn{3}{|l|}{ No. $/ \%$ of infected ticks } \\
\hline & & $\begin{array}{l}\text { Borrelia burgdorferi } \\
\text { s.1. }\end{array}$ & $\begin{array}{l}\text { Anaplasma } \\
\text { phagocytophilum }\end{array}$ & SFG Rickettsia $\mathrm{spp}$ \\
\hline Larvae & 1 & $0 / 0$ & $0 / 0$ & $0 / 0$ \\
\hline Females & 7 & $1 / 14.3$ & $0 / 0$ & $3 / 42.9$ \\
\hline Total & 8 & $1 / 12.5$ & $0 / 0$ & $3 / 37.5$ \\
\hline
\end{tabular}


sheep ticks is not surprising. Infection rate of questing I. ricinus with borreliae in different collection sites in Poland may even reach up to $58.3 \%$ (Stańczak and Kubica-Biernat 1999). In Europe, the metaanalysis of the mean prevalence of Borrelia spp. infections in ticks indicates that the overall mean was $18.6 \%$ in adults and $10.1 \%$ in nymphs (Rauter and Hartung 2005). The obtained fla gen sequence differed by one nucleotide with, among the other, sequences of $B$. garinii isolate O2-27 from I. ricinus, Lower Silesia, Poland (KF836512), B. garinii strain J3-1F-IR from I. canisuga feeding on a red fox Vulpes vulpes, Poland (KF918608) (Wodecka et al. unpublished), and B. garinii strain BRZ38 from I. ricinus collected in Moravia, Czech Republic (JF828688) (Norek et al. unpublished). In Europe, $B$. garinii follows $B$. afzelii as the most prevalent $B$. burgdorferi s.l. genospecies (Reye et al. 2010). In Poland, the prevalence of $B$. garinii in infected ticks ranged between 10.1 and $21.4 \%$ (Cisak et al. 2006; Kiewra et al. 2014; Stańczak et al. 2000; Strzelczyk et al. 2006).

Rickettsiae were another pathogen identified in I. ricinus in this study. Their presence was confirmed by detection of the specific fragments of gltA and 16S rRNA gene, but no positive results were obtained when using primers targeting a fragment of the ompA gene. This suggested that detected rickettsiae belonged to the species $R$. helvetica as it is one of the few SFG rickettsiae in which omp $A$ gene is not amplified (Roux et al. 1996; Parola et al. 1998). Further sequencing of gltA fragment enabled definitive identification. The sequence was $100 \%$ comparable with sequences of $R$. helvetica isolated from $I$. ricinus ticks along Europe, from France (KF447530), Germany (JX627379, strain 4TI3; KC007126, isolate 6DI76), Romania (JX040636; strain 99Bc/Romania) to Russia (AM418450, isolate 1-97). Moreover, the consensus sequence of the 16S rRNA gene was identical to $R$. helvetica clone CsFC (GQ413963) isolated from human cerebrospinal fluid (Påhlson, unpublished), Rickettsia sp. IP1 isolated from ticks in Japan (AF 394904, AF394905) (Fournier et al. 2002), and R. helvetica strain C9P9 from France (L36212) (Roux and Raoult 1995). $R$. helvetica is widely distributed in the tick population in Poland with the mean prevalence up to $10.6 \%$ (Chmielewski et al. 2009; Stańczak et al. 2008) and was also noted in ticks feeding on deer hosts (10.8-19.0 \%) (Stańczak et al. 2009).

It is significant, however, this is the first time $R$. helvetica and B. garinii have been noted in I. ricinus collected from bats. Furthermore, this is the first PCR positivity to the one of genospecies of B. burgdorferi s.l. and SFG Rickettsia spp. not only in the I. ricinus attached to bats but also in the all hard tick species collected from bats. Thus, I. ricinus might be the reservoir for these disease agents not only among terrestrial vertebrates, birds, and humans but also bats. However, since this species rarely parasitizes bats $(8$ specimens per ca. 4000 ticks picked from bats- $0.2 \%$ ), it does not play a significant role in the pathogen transmission among bats compared to other vertebrates.

These results have expanded our knowledge about tick vectors and provide a platform for further observation and more detailed studies on the possible role of ticks and other ectoparasites as the vectors of TBD in bats.

Open Access This article is distributed under the terms of the Creative Commons Attribution 4.0 International License (http:// creativecommons.org/licenses/by/4.0/), which permits unrestricted use, distribution, and reproduction in any medium, provided you give appropriate credit to the original author(s) and the source, provide a link to the Creative Commons license, and indicate if changes were made.

\section{References}

Arthur DR (1956) The Ixodes ticks of Chiroptera (Ixodoidea, Ixodidae). J Parasitol 42:180-196

Bown KJ, Lambin X, Telford GR, Ogden NH, Telfer S, Woldehiwet Z, Birtles RJ (2008) Relative importance of Ixodes ricinus and Ixodes trianguliceps as vectors for Anaplasma phagocytophilum and Babesia microti in field vole (Microtus agrestis) populations. Appl Environ Microbiol 74:7118-7125

Chmielewski T, Podsiadły E, Karbowiak G, Tylewska-Wierzbanowska S (2009) Rickettsia spp. in ticks, Poland. Emerg Infect Dis 15:486488

Cisak E, Wójcik-Fatla A, Stojek NM, Chmielewska-Badora J, Zwoliński J, Buczek A, Dutkiewicz J (2006) Prevalence of Borrelia burgdorferi genospecies in Ixodes ricinus ticks from Lublin region (eastern Poland). Ann Agric Environ Med 13:301-306

Eisen L, Lane RS (2002) Vectors of Borrelia burgdorferi sensu lato. In: Gray J, Kahl O, Lane RS, Stanek G (eds) Lyme borreliosis: biology epidemiology and control. CABI Publishing, Wallingford, pp 91115

Fenton MB, Simmons NB (2015) Bats: a world of science and mystery. University of Chicago Press, Chicago

Filippova NA (1977) Iksodowyje kleszczy podsiem. Ixodinae. Fauna SSSR. Paukoobraznyje, [Ixodid Ticks of the Subfamily Ixodinae. Fauna of the USSR. Arachnidea], vol 4. Nauka, Leningrad

Fournier PE, Fujita H, Takada N, Raoult D (2002) Genetic identification of rickettsiae isolated from ticks in Japan. J Clin Microbiol 40:21762181

Gray J (1998) Review the ecology of ticks transmitting Lyme borreliosis. Exp Appl Acarol 22:249-258

Haitlinger R (1978) Pasożyty zewnętrzne nietoperzy Dolnego Śląska. III. Spinturnicidae, Argasidae, Ixodidae (Acarina), [External parasites of the Lower Silesian bats. III. Spinturnicidae, Argasidae, Ixodidae (Acarina)]. Wiad Parazytol 24:478-490

Hillyard PD (1996) Ticks of North-West Europe. Field Studies Council, Shrewsbury

Hornok S, Kovács R, Meli ML, Gönczi E, Hofmann-Lehmann R, Kontschán J, Gyuranecz M, Dán A, Molnár V (2012) First detection of bartonellae in a broad range of bat ectoparasites. Vet Microbiol 159:541-543

Hornok S, Kontschán J, Kováts D, Kovács R, Angyal D, Görföl T, Polacsek Z, Kalmár ZD (2014) Bat ticks revisited: Ixodes ariadnae sp. nov. and allopatric genotypes of $I$. vespertilionis in caves of Hungary. Parasit Vectors 7:202

Hubbard MJ, Baker AS, Cann KJ (1998) Distribution of Borrelia burgdorferi s.l. spirochaete DNA in British ticks (Argasidae and 
Ixodidae) since the 19th century, assessed by PCR. Med Vet Entomol 12:89-97

Jongejan F, Uilenberg G (2004) The global importance of ticks. Parasitology 129:3-14

Kiewra D, Stańczak J, Richter M (2014) Ixodes ricinus ticks (Acari, Ixodidae) as a vector of Borrelia burgdorferi sensu lato and Borrelia miyamotoi in Lower Silesia, Poland-preliminary study. Ticks Tick Borne Dis 5:892-8977

Loftis AD, Gill JS, Schriefer ME, Levin ML, Eremeeva ME, Gilchrist MJR, Dasch GA (2005) Detection of Rickettsia, Borrelia, and Bartonella in Carios kelleyi (Acari: Argasidae). J Med Entomol 42:473-480

Manilla G (1998) Fauna d'Italia Acari, Ixodida. Edizio ni Calderini, Bologna

Massung RF, Mauel MJ, Owens JH, Allan N, Courtney JW, Stafford KC, Mather T (2002) Genetic variants of Ehrlichia phagocytophila, Rhode Island and Connecticut. Emerg Infect Dis 8:467-472

Nilsson K, Jaenson GT, Uhnoo I, Lindquist O, Pettersson B, Uhle'n M, Friman G, Påhlson C (1997) Characterization of a spotted fever group rickettsia from Ixodes ricinus ticks in Sweden. J Clin Microbiol 35:243-247

Nowak-Chmura M, Siuda K (2012) Ticks of Poland. Review of contemporary issues and latest research. Ann Parasitol 58:125-155

Parola P, Beati L, Cambon M, Raoult D (1998) First isolation of Rickettsia helvetica from Ixodes ricinus ticks in France. Eur J Clin Microbiol Infect Dis 17:95-100

Piksa K, Górz A, Nowak-Chmura M, Siuda K (2013) Mass occurrence of Ixodes vespertilionis (Acari: Ixodidae) in caves, on bats roosting in caves and in a nursery colony. Int J Acarol 39:257-262

Piksa K, Górz A, Nowak-Chmura M, Siuda K (2014) The patterns of seasonal activity, of Ixodes vespertilionis (Acari: Ixodidae) on Rhinolophus hipposideros in nursery colonies. Ticks Tick-Borne Dis 5:69-74

Raoult D, Lakos A, Fenollar F, Beytout J, Brouqui P, Fournier P-E (2002) Spotless rickettsiosis caused by Rickettsia slovaca and associated with Dermacentor ticks. Clin Infect Dis 34:1331-1336

Rauter C, Hartung T (2005) Prevalence of Borrelia burgdorferi sensu lato genospecies in Ixodes ricinus ticks in Europe: a metaanalysis. Appl Environ Microbiol 71:7203-7216

Regnery RL, Spruill CL, Plikaytis BD (1991) Genotypic identification of rickettsiae and estimation of intraspecies sequence divergence for portions of two rickettsial genes. J Bacteriol 173:1576-1589

Reye AL, Hubschen JM, Sausy A, Muller CP (2010) Prevalence and seasonality of tock-borne pathogens in questing Ixodes ricinus tick from Luxemburg. Appl Environ Microbiol 76:2923-2931

Rijpkema S, Golubic D, Moelkenboer M, Verbeek-De Kruif N, Schellekens J (1996) Identification of four genomic groups of Borrelia burgdorferi sensu lato in Ixodes ricinus ticks collected in a Lyme borreliosis endemic region of northern Croatia. Exp Appl Acarol 20:23-30
Roux V, Raoult D (1995) Phylogenetic analysis of the genus Rickettsia by 16S rDNA sequencing. Res Microbiol 146:385-396

Roux V, Fournier PE, Raoult D (1996) Differentiation of spotted fever group rickettsiae by sequencing and analysis of restriction fragment length polymorphism of PCR-amplified DNA of the gene encoding the protein rOmpA. J Clin Microbiol 34:2058-2065

Ševčík M, Krištofík J, Uhrin M, Benda P (2010) New records of ticks (Acari: Ixodidae) parasitizing on bats in Slovakia. Vespertilio 1314:139-147

Siuda K (1993) Kleszcze Polski (Acari: Ixodida) [Ticks (Acari: Ixodida) of Poland. Part II Taxonomy and distribution], Polskie Towarzystwo Parazytologiczne, Warszawa

Siuda K, Stanko M, Piksa K, Górz A (2009) Ticks (Acari: Ixodida) parasitizing bats in Poland and Slovakia. Wiad Parazytol 55:39-45

Socolovschi C, Kernif T, Raoult D, Parola P (2012) Borrelia, Rickettsia, and Ehrlichia species in bat ticks, France, 2010. Emerg Infect Dis 18:1966

Stańczak J (2006) The occurrence of spotted fever group (SFG) rickettsiae in Ixodes ricinus ticks (Acari: Ixodidae) in northern Poland. Ann N Y Acad Sci 1078:512-514

Stańczak J, Kubica-Biernat B (1999) Prevalence of Borrelia burgdorferi in ticks from different areas of Poland. Zent bl Bakteriol 286:704 705

Stańczak J, Kubica-Biernat B, Racewicz M, Kruminis-Lozowska W (2000) Detection of three genospecies of Borrelia burgdorferi sensu lato in Ixodes ricinus ticks collected in different regions of Poland. Int J Med Microbiol 290:559-566

Stańczak J, Gabre RM, Kruminis-Lozowska W, Racewicz M, KubicaBiernat B (2004) Ixodes ricinus as a vector of Borrelia burgdorferi sensu lato, Anaplasma phagocytophilum and Babesia microti in urban and suburban forests. Ann Agric Environ Med 11:109-114

Stańczak J, Racewicz M, Michalik J, Buczek A (2008) Distribution of Rickettsia helvetica in Ixodes ricinus tick populations in Poland. Int $\mathrm{J}$ Med Microbiol 298:231-234

Stańczak J, Racewicz M, Michalik M, Cieniuch S, Sikora B, Skoracki M (2009) Prevalence of infection with Rickettsia helvetica in feeding ticks and their hosts in western Poland. Clin Microbiol Infect 15(Suppl 2):328-329

Strzelczyk JK, Wiczkowski A, Kwaśniewski M, Zalewska-Ziob M, Strzelczyk J, Gawron K, Adamek B, Spausta G (2006) Prevalence of Borrelia burgdorferi sensu lato genospecies in Ixodes ricinus ticks from recreational areas of Silesia. Adv Clin Exp Med 15: 1003-1008

Süss J, Klaus C, Gerstengarbe FW, Werner PC (2008) What makes ticks tick? Climate change, ticks, and tick-borne diseases. J Travel Med 15:39-45

Wodecka B, Rymaszewska A, Sawczuk M, Skotarczak B (2009) Detectability of tick-borne agents in the blond of dogs, undergoing treatment for borreliosis. Ann Agric Environ Med 16:9-14 